\title{
Burnout among Healthcare Workers during COVID-19 Pandemic in India: Results of a Questionnaire-based Survey
}

\author{
Ruchira W Khasne ${ }^{1}$, Bhagyashree S Dhakulkar ${ }^{2}$, Hitendra C Mahajan ${ }^{3}$, Atul P Kulkarni ${ }^{4}$
}

\begin{abstract}
Background: Burnout, a state of physical and emotional exhaustion, in healthcare workers (HCWs) is a major concern. The prevalence of burnout, due to COVID-19 pandemic in India, is unknown. We therefore conducted this survey.

Materials and methods: A questionnaire-based survey using Copenhagen Burnout Inventory was carried out among HCWs looking after COVID-19 patients. Questionnaire was sent to the HCWs, using WhatsApp Messenger, and voluntary participation was sought. We received responses from 2026 HCWs. Burnout was assessed in personal, work, and client-related (COVID-19 pandemic-related) domains. Burnout was defined at a cut-off score of 50 for each domain.

Results: The prevalence of personal burnout was $44.6 \%$ (903), work-related burn-out was only $26.9 \%$ (544), while greater than half of the respondents $(1,069,52.8 \%)$ had pandemic-related burnout. Younger respondents (21-30 years) had higher personal and work-related burnout. The prevalence of personal and work-related burnout was significantly $(p<0.01)$ higher among females. The doctors were 1.64 times, and the support staff were 5 times more likely to experience pandemic-related burnout.

Conclusion: There is a significant prevalence of burnout during the COVID-19 pandemic among HCWs, in particular, doctors and support staff. Female respondents had higher prevalence. We suggest that the management should be proactive and supportive in improving working conditions and providing assurance to the HCWs. The long-term effects of the current pandemic need to be assessed later.

Keywords: Burnout, Copenhagen burnout inventory, COVID-19 pandemic, Mental health.

Indian Journal of Critical Care Medicine (2020): 10.5005/jp-journals-10071-23518
\end{abstract}

\section{INTRODUCTION}

Burnout is increasingly being recognized globally as a major concern, affecting physical and mental well-being of HCWs. During the current COVID-19 pandemic, closing down of international and state borders, strict city, and also areawise lockdown has affected HCWs and their families as well, causing excessive negative psychological effects. Burnout, a state of "emotional exhaustion" among professionals, was first described in the mid-1970s, by Freudenberger and Maslach. Burnout is defined as a state of physical, emotional, and mental exhaustion that results from long-term involvement in work situations that are emotionally demanding. It is a multidimensional syndrome comprising emotional exhaustion, depersonalization, and reduced sense of personal accomplishment. ${ }^{1-3}$ In the past two decades, several viral outbreaks have occurred, such as SARS, MERS, Ebola, etc. Kisley et al. in a recent review reported that such outbreaks resulted in psychological distress and posttraumatic stress in the HCWs. Of the many causative factors described by Kisely et al., clinical factors (contact with affected patients, forced redeployment to look after affected patients, training perceived to be inadequate), personal factors (fear of quarantine, particularly in staff with children at home, and infected family member), and societal factors (societal stigma against hospital workers) seem to be particularly relevant in Indian healthcare scenario. ${ }^{4}$ Burnout, apart from being personally harmful, can lead to suboptimal patient care. ${ }^{5}$

Globally, while the researchers are pursuing many avenues to prevent and treat the COVID-19 menace, its psychological impact among HCWs has also been assessed. However, not many steps are being taken by the administrators of the healthcare organizations to mitigate the effects of psychological distress on the HCWs. The World Health Organization (WHO) has formally recognized this risk
1,2Department of Critical Care Medicine, Ashoka Medicover Hospital, Wadala, Nashik, Maharashtra, India

${ }^{3}$ Department of Anesthesiology, Ashoka Medicover Hospital, Wadala, Nashik, Maharashtra, India

${ }^{4}$ Division of Critical Care Medicine, Department of Anesthesia, Critical Care and Pain, Tata Memorial Hospital, Homi Bhabha National Institute, Parel (E), Mumbai, Maharashtra, India

Corresponding Author: Atul P Kulkarni, Division of Critical Care Medicine, Department of Anesthesia, Critical Care and Pain, Tata Memorial Hospital, Homi Bhabha National Institute, Parel (E), Mumbai, Maharashtra, India, Phone: +91 9869077526, e-mail: kaivalyaak@ yahoo.co.in

How to cite this article: Khasne RW, Dhakulkar BS, Mahajan HC, Kulkarni AP. Burnout among Healthcare Workers during COVID-19 Pandemic in India: Results of a Questionnaire-based Survey. Indian J Crit Care Med 2020;24(8):664-671.

Source of support: Nil

Conflict of interest: None

and has released a document about psychosocial consideration during COVID-19. ${ }^{6}$

Maslach and Jackson first described Maslach Burnout Inventory (MBI) in 1981. ${ }^{3}$ The $\mathrm{MBI}$ defines burnout based on three facets, presence of emotional exhaustion, depersonalization, and lack of personal fulfillment. Kristensen questioned the reliability of $\mathrm{MBI}$ with many arguments and to overcome the drawbacks of $\mathrm{MBI}$, introduced the Copenhagen Burnout Inventory (CBI). ${ }^{7}$

A Chinese study by Lai et al. found that HCWs responsible for the care of COVID-19 patients were more likely to have symptoms

() The Author(s). 2020 Open Access This article is distributed under the terms of the Creative Commons Attribution 4.0 International License (https://creativecommons. org/licenses/by-nc/4.0/), which permits unrestricted use, distribution, and non-commercial reproduction in any medium, provided you give appropriate credit to the original author(s) and the source, provide a link to the Creative Commons license, and indicate if changes were made. The Creative Commons Public Domain Dedication waiver (http://creativecommons.org/publicdomain/zero/1.0/) applies to the data made available in this article, unless otherwise stated. 
of depression, anxiety, insomnia, and distress. ${ }^{8}$ Xiao et al. looked at the effect of social support on the mental health, using structural equation model (SEM) analysis, in a prospective observational study. ${ }^{9}$ The questionnaire was served to 180 physicians and nurses, treating COVID-19 infected patients, at a hospital under Wuhan University School of Medicine. They found that the respondents had high levels of anxiety, stress, and self-efficacy, which depended on the quality of sleep and social support. There are no studies evaluating the mental health status and prevalence of burnout in Indian HCWs involved in the care of COVID-19 patients. We, therefore, conducted this survey using the $C B I$ to evaluate the prevalence of burnout.

\section{Materials and Methods}

Approval for survey was obtained from an independent ethics committee. We sent an introductory note along with the questionnaire, which explained the intent of the survey, and an assurance that strict anonymity and confidentiality of data will be maintained. The questionnaire was created using Google Sheet. Though this has an optional field for e-mail address of the respondents, we did not choose this option. Thus, the identity of the respondents was not known to any of the investigators (Supplementary material at ijccm.org). Since it was a survey of HCWs, a response was taken as an implied or implicit consent. We carried out a prospective, cross-sectional, online survey to evaluate the prevalence of burnout during the COVID-19 pandemic. We collected data on age, gender, and job profile. The questionnaire was based on CBI. The questionnaire was prepared using Google docs that had 31 questions in total. This was sent to the contacts of all the investigators, using the WhatsApp Messenger (simply WhatsApp), an American freeware, crossplatform messaging, and voice over IP (VoIP) service owned by Facebook, Inc. We included all HCWs (doctors, nurses, paramedics, i.e., dieticians, physiotherapists, pharmacists, and ward boys and administrative staff. Request to participate was sent twice at an interval of 1 week.

The questionnaire had 5 general questions and specific questions in 3 domains of burnout. General questions were about job profile, age, gender, and working environment. The first domain, based on personal burnout (i.e., without a specific attribution), had five items. The second domain (perceived to be related to person's work), based on the work-related burnout, had six items. The third domain was based on client-related burnout (perceived as related to the persons' work with client, i.e., COVID-19 pandemic) had 13 items. $^{7}$

All items had five response categories each. Options mentioned in questionnaire were in two formats: five response categories in Likert scale (for intensity) "a very high degree" to "a very low degree"; others for frequency from "always" to "never or almost never." Each scale ranged from 0 to 100 points, with higher the score suggesting higher level of burnout. We averaged the scores as the total score and defined burnout as CBI score $>50$.

\section{Statistical Analysis}

Data were obtained from Google sheets and analyzed using IBM SPSS $^{\circledast}$ Statistics version 21 . Variables measured on nominal scale were summarized using proportions (\%). Mean scores (mean $\pm \mathrm{SD}$ ) in personal, work-related, and client-related (pandemic related) domains were calculated using the 0 - to 100-point scale. Respondents with a mean score of $>50$ were classified as experiencing burnout. Also, the responses $(n, \%)$ and average scores were calculated separately for each question. The mean burnout scores in each domain were compared using ANOVA, followed by Tukey's multiple comparison test. Categorical variables were analyzed using Pearson's $\chi^{2}$ test. Univariate analysis was performed to check for association between personal, work-related, and client-related (pandemic related) burnout and demographic factors and reported using odds ratio (OR). Binary regression analysis was not done, as there were only four independent variables; of these, only two were significant on univariate analysis for each type of burnout. A $p$ value of $<0.05$ was considered statistically significant.

\section{Results}

We received responses from $2026 \mathrm{HCWs}$. All the respondents were over the age of 21 years. Most participant's (1,642, 81\%) age ranged between 21 years and 50 years. There were 1,117 (55\%) males. Majority of the respondents $(82.3 \%, 1667)$ were doctors. Most respondents were working in high-risk areas $(86 \%, 1743)$. Nearly all $(2,001,98.8 \%)$ respondents felt that mental health was as important as physical health (Table 1).

The mean $( \pm S D)$ scores of the personal, work-related, and pandemic-related burnout domains of the questionnaire were 49.72 ( \pm 18.68$), 39.69( \pm 20.43)$, and $51.37( \pm 15.12)$, respectively (Tables 2 to 4). The difference between these scores was significant $(F=244.1, p<0.001)$. The mean pandemic-related burnout score was significantly higher than personal and work-related burnout scores $(p<0.01)$. Also, the difference between mean personal burnout score and work-related burnout score was statistically significant $(p<0.05)$. Nearly half $(1,120,55.3 \%)$ of the respondents feared contracting COVID-19 infection, and 1,357 (66.9\%) respondents feared carrying the infection home. Nearly one-fifth of respondents $(461,22.7 \%)$ expressed fear of death while working. A quarter of respondents $(540,26.6 \%)$ felt that they were not welcomed by their community. Considering the 50-point cut-off in the mean scores of each domain for every participant, the prevalence of personal burnout was $44.6 \%$ (903) and that of work-related burnout was

Table 1: Age distribution, job profile, and work location of participants $(n=2,026)$

\begin{tabular}{lc}
\hline Variable & Frequency (\%) \\
\hline Age & \\
$21-30$ years & $380(18.8)$ \\
$31-40$ years & $784(38.7)$ \\
$41-50$ years & $478(23.6)$ \\
$51-60$ years & $255(12.6)$ \\
$>61$ years & $129(6.4)$ \\
Job profile & \\
Doctor & $1,667(82.3)$ \\
Nurse & $198(9.8)$ \\
Administration staff & $90(4.4)$ \\
Paramedic (dietitian, physiotherapist, & $43(2.1)$ \\
pharmacist, etc.) & \\
Support staff (ward boy, etc.) & $28(1.4)$ \\
Work environment & \\
High risk (ER, OPD, Wards, ICU, OT) & $1,743(86.0)$ \\
Low risk (other areas) & $283(14.0)$ \\
\hline
\end{tabular}


Table 2: Domain 1: Personal burnout and distribution of responses $(n=2,026)$

\begin{tabular}{|c|c|c|c|c|c|c|}
\hline Questions & $\begin{array}{l}\text { Always or to a very } \\
\text { high degree }\end{array}$ & $\begin{array}{l}\text { Often or to a high } \\
\text { degree }\end{array}$ & $\begin{array}{l}\text { Sometimes or } \\
\text { somewhat }\end{array}$ & $\begin{array}{l}\text { Seldom or to a low } \\
\text { degree }\end{array}$ & $\begin{array}{l}\text { Never or to a very } \\
\text { low degree }\end{array}$ & Mean score \\
\hline $\begin{array}{l}\text { How often are you physi- } \\
\text { cally exhausted? }\end{array}$ & $162(8.0 \%)$ & $598(29.5 \%)$ & $1,002(49.5 \%)$ & $194(9.6 \%)$ & $70(3.5 \%)$ & $57.26 \pm 21.87$ \\
\hline $\begin{array}{l}\text { How often are you emo- } \\
\text { tionally exhausted? }\end{array}$ & $168(8.3 \%)$ & $589(29.1 \%)$ & $948(46.8 \%)$ & $236(11.6 \%)$ & $85(4.2 \%)$ & $56.40 \pm 22.93$ \\
\hline $\begin{array}{l}\text { How often do you think: } \\
\text { "I can't take it anymore?" }\end{array}$ & $90(4.4 \%)$ & $300(14.8 \%)$ & $937(46.2 \%)$ & $498(24.6 \%)$ & 201 (9.9\%) & $44.82 \pm 24.06$ \\
\hline $\begin{array}{l}\text { How often do you feel } \\
\text { weak and susceptible to } \\
\text { illness? }\end{array}$ & $70(3.5 \%)$ & $299(14.8 \%)$ & $948(46.8 \%)$ & $523(25.8 \%)$ & $186(9.2 \%)$ & $44.37 \pm 23.19$ \\
\hline $\begin{array}{l}\text { How often do you feel } \\
\text { worn out (extremely } \\
\text { tired)? }\end{array}$ & $72(3.6 \%)$ & 334 (16.5\%) & 947 (46.7\%) & $525(25.9 \%)$ & $148(7.3 \%)$ & $45.77 \pm 22.78$ \\
\hline Average score & & & & & & $49.72 \pm 18.68$ \\
\hline
\end{tabular}

Table 3: Domain 2: Work-related burnout and distribution of responses $(n=2,026)$

\begin{tabular}{|c|c|c|c|c|c|c|}
\hline Questions & $\begin{array}{l}\text { Always or to a very } \\
\text { high degree }\end{array}$ & $\begin{array}{l}\text { Often or to a high } \\
\text { degree }\end{array}$ & $\begin{array}{l}\text { Sometimes or } \\
\text { somewhat }\end{array}$ & $\begin{array}{l}\text { Seldom or to a low } \\
\text { degree }\end{array}$ & $\begin{array}{l}\text { Never or to a very } \\
\text { low degree }\end{array}$ & Mean score \\
\hline $\begin{array}{l}\text { Are you exhausted in the } \\
\text { morning at the thought } \\
\text { of another day at work? }\end{array}$ & $91(4.5 \%)$ & 232 (11.5\%) & $816(40.3 \%)$ & $482(23.8 \%)$ & 405 (20.0\%) & $39.17 \pm 26.74$ \\
\hline $\begin{array}{l}\text { Do you feel that every } \\
\text { working hour is tiring for } \\
\text { you? }\end{array}$ & $80(3.9 \%)$ & 214 (10.6\%) & $716(35.3 \%)$ & 590 (29.1\%) & $426(21.0 \%)$ & $36.82 \pm 26.44$ \\
\hline $\begin{array}{l}\text { Do you have enough } \\
\text { energy for family and } \\
\text { friends during leisure } \\
\text { time? }\end{array}$ & $436(21.5 \%)$ & $657(32.4 \%)$ & $670(33.1 \%)$ & $201(9.9 \%)$ & $62(3.1 \%)$ & $35.14 \pm 25.67$ \\
\hline $\begin{array}{l}\text { Do you feel that your } \\
\text { work is emotionally } \\
\text { exhausting? }\end{array}$ & 147 (7.3\%) & $498(24.6 \%)$ & $844(41.7 \%)$ & $332(16.4 \%)$ & $205(10.1 \%)$ & $50.62 \pm 26.27$ \\
\hline $\begin{array}{l}\text { Does your work frustrate } \\
\text { you? }\end{array}$ & $75(3.7 \%)$ & $242(11.9 \%)$ & 765 (37.8\%) & $448(22.1 \%)$ & $496(24.5 \%)$ & $37.07 \pm 27.40$ \\
\hline $\begin{array}{l}\text { Do you feel burnt out } \\
\text { (complete physical or } \\
\text { mental exhaustion) be- } \\
\text { cause of your work? }\end{array}$ & $101(5.0 \%)$ & $268(13.2 \%)$ & 772 (38.1\%) & 436 (21.5\%) & 449 (22.2\%) & $39.34 \pm 27.97$ \\
\hline Average score & & & & & & $39.69 \pm 20.43$ \\
\hline
\end{tabular}

$26.9 \%$ (544). A little more than half $(1,069,52.8 \%)$ of the respondents were experiencing pandemic-related burnout (Table 5).

The prevalence of personal, work-related, and pandemicrelated burnout among respondents aged $21-30$ years was $53.7 \%, 32.9 \%$, and $49.7 \%$, respectively. While the prevalence of personal and work-related burnout among those between 31 and 40 years was similar in the age group of 31-40 years, there was a marked increase in pandemic-related burnout in this age category $(\mathrm{OR}=1.49, p<0.01)$. In comparison to the first age category, respondents over 40 years demonstrated significantly lower prevalence of personal and work-related burnout. But, significant difference was not seen in pandemic-related burnout, except in those aged $>61$ years who showed lower rates $(O R=0.64$, $p=0.03$ ).

The prevalence of personal (41.3\% vs $48.6 \%)$ and work-related burnout $(25.0 \%$ vs $29.1 \%)$ was significantly $(p<0.01)$ higher among female respondents, the odds ratio for experiencing personal and work-related burnout were $1.35(95 \% \mathrm{Cl} 1.13-1.61, p<0.01)$ and 1.24 (95\% Cl 1.01-1.50, $p<0.03)$, respectively, as compared to males.

The prevalence of personal and work-related burnout among doctors, nurses, and paramedics was similar to that seen in the administrative staff, but support staff had lower prevalence of personal (10.7\%) and work-related (14.3\%) burnout. However, this finding needs to be investigated in further studies, because the number of administrative and support staff was much smaller as compared to the doctors and paramedical staff in this study. However, doctors were 1.64 times more likely $(\mathrm{OR}=1.64, p=0.04)$, and support staff was 5 times more likely ( $O R=5.02, p<0.01)$, to experience pandemic-related burnout than the administrative staff.

Respondents working in high-risk hospital environment demonstrated significantly greater prevalence of work-related ( $27.8 \%$ vs $21.2 \%, p<0.01)$ and pandemic-related burnout $(53.9 \%$ vs $45.6 \%, p<0.01)$, but the difference between personal burnout rates in these groups was not statistically significant $(p=0.24)$. 
Table 4: Domain 3: Pandemic-related burnout and distribution of responses $(n=2,026)$

\begin{tabular}{|c|c|c|c|c|c|c|}
\hline Questions & $\begin{array}{l}\text { Always or to a very } \\
\text { high degree }\end{array}$ & $\begin{array}{l}\text { Often or to a high } \\
\text { degree }\end{array}$ & $\begin{array}{l}\text { Sometimes or } \\
\text { somewhat }\end{array}$ & $\begin{array}{l}\text { Seldom or to a low } \\
\text { degree }\end{array}$ & $\begin{array}{l}\text { Never or to a very } \\
\text { low degree }\end{array}$ & Mean score \\
\hline $\begin{array}{l}\text { Do you feel it is hard } \\
\text { to work in the current } \\
\text { scenario? }\end{array}$ & $327(16.1 \%)$ & $618(30.5 \%)$ & $716(35.3 \%)$ & $224(11.1 \%)$ & $141(7.0 \%)$ & $59.45 \pm 27.35$ \\
\hline $\begin{array}{l}\text { Does it drain more of } \\
\text { your energy to work dur- } \\
\text { ing the current scenario? }\end{array}$ & $287(14.2 \%)$ & $654(32.3 \%)$ & 657 (32.4\%) & 274 (13.5\%) & $154(7.6 \%)$ & $57.97 \pm 27.70$ \\
\hline $\begin{array}{l}\text { Do you find it fruitful } \\
\text { while performing your } \\
\text { work during the current } \\
\text { scenario? }\end{array}$ & $269(13.3 \%)$ & $583(28.8 \%)$ & 774 (38.2\%) & $279(13.8 \%)$ & $121(6.0 \%)$ & $42.60 \pm 26.32$ \\
\hline $\begin{array}{l}\text { Do you feel that you } \\
\text { are giving more than } \\
\text { what you get back while } \\
\text { working in the current } \\
\text { scenario? }\end{array}$ & $563(27.8 \%)$ & $587(29.0 \%)$ & $581(28.7 \%)$ & $170(8.4 \%)$ & $125(6.2 \%)$ & $65.96 \pm 28.78$ \\
\hline $\begin{array}{l}\text { Do you hesitate to work } \\
\text { during this current } \\
\text { scenario? }\end{array}$ & $232(11.5 \%)$ & $342(16.9 \%)$ & 791 (39.0\%) & 381 (18.8\%) & $280(13.8 \%)$ & $48.33 \pm 29.20$ \\
\hline $\begin{array}{l}\text { Do you feel depressed } \\
\text { because of the current } \\
\text { scenario? }\end{array}$ & $154(7.6 \%)$ & 308 (15.2\%) & $818(40.4 \%)$ & 346 (17.1\%) & $400(19.7 \%)$ & $43.46 \pm 29.03$ \\
\hline $\begin{array}{l}\text { Do you feel that your } \\
\text { patience is tested while } \\
\text { working in the current } \\
\text { scenario? }\end{array}$ & $526(26.0 \%)$ & $673(33.2 \%)$ & $628(31.0 \%)$ & 135 (6.7\%) & $64(3.2 \%)$ & $68.04 \pm 25.53$ \\
\hline $\begin{array}{l}\text { Do you feel lockdown } \\
\text { due to the current } \\
\text { scenario has added stress } \\
\text { on you? }\end{array}$ & $284(14.0 \%)$ & $438(21.6 \%)$ & 770 (38.0\%) & 266 (13.1\%) & $268(13.2 \%)$ & $52.52 \pm 29.87$ \\
\hline $\begin{array}{l}\text { Do you have fear to catch } \\
\text { COVID-19 infection while } \\
\text { working in the current } \\
\text { scenario? }\end{array}$ & $613(30.3 \%)$ & $507(25.0 \%)$ & $615(30.4 \%)$ & $180(8.9 \%)$ & $111(5.5 \%)$ & $66.42 \pm 28.91$ \\
\hline $\begin{array}{l}\text { Do you have a fear of } \\
\text { family members catching } \\
\text { infection because of your } \\
\text { work exposure? }\end{array}$ & $868(42.8 \%)$ & $489(24.1 \%)$ & $456(22.5 \%)$ & $140(6.9 \%)$ & $73(3.6 \%)$ & $73.93 \pm 27.98$ \\
\hline $\begin{array}{l}\text { Do you feel welcomed by } \\
\text { the community because } \\
\text { you are an HCW and } \\
\text { working in the current } \\
\text { scenario? }\end{array}$ & $287(14.2 \%)$ & $448(22.1 \%)$ & $751(37.1 \%)$ & 363 (17.9\%) & 177 (8.7\%) & $46.24 \pm 28.44$ \\
\hline $\begin{array}{l}\text { Are you indulging in } \\
\text { any substance abuse } \\
\text { (alcohol/drugs/smok- } \\
\text { ing) during this period of } \\
\text { lockdown? }\end{array}$ & $43(2.1 \%)$ & $65(3.2 \%)$ & $446(22.0 \%)$ & 261 (12.9\%) & $1,211(59.8 \%)$ & $18.76 \pm 25.92$ \\
\hline $\begin{array}{l}\text { Do you have a fear of } \\
\text { death while working in } \\
\text { the current scenario? }\end{array}$ & $166(8.2 \%)$ & 295 (14.6\%) & 747 (36.9\%) & $422(20.8 \%)$ & $396(19.5 \%)$ & $42.76 \pm 29.37$ \\
\hline $\begin{array}{l}\text { Do you feel you are being } \\
\text { properly protected by the } \\
\text { hospital while working in } \\
\text { the current scenario? }\end{array}$ & 226 (11.2\%) & 397 (19.6\%) & $742(36.6 \%)$ & 399 (19.7\%) & $262(12.9 \%)$ & $50.91 \pm 29.11$ \\
\hline $\begin{array}{l}\text { Do you feel you are being } \\
\text { supported by colleagues } \\
\text { during the current } \\
\text { scenario? }\end{array}$ & 535 (26.4\%) & $616(30.4 \%)$ & $626(30.9 \%)$ & $174(8.6 \%)$ & $75(3.7 \%)$ & $33.19 \pm 26.73$ \\
\hline Average score & & & & & & $51.37 \pm 15.12$ \\
\hline
\end{tabular}


Table 5: Univariate analysis of age, gender, job profile, and working environment on personal, work-related, and pandemic-related burnout on developing personal, work-related, and pandemic-related burnout*

\begin{tabular}{|c|c|c|c|c|c|c|c|c|c|}
\hline \multirow[b]{2}{*}{ Variable } & \multicolumn{3}{|c|}{ Personal burnout, $(n=903)(44.6)$} & \multicolumn{3}{|c|}{ Work-related burnout, $(n=544)(26.9)$} & \multicolumn{3}{|c|}{$\begin{array}{l}\text { Pandemic-related burnout, }(n=1,069) \\
(52.8)\end{array}$} \\
\hline & $n(\%)$ & OR $[95 \% \mathrm{Cl}]$ & pvalue & $n(\%)$ & OR $[95 \% \mathrm{Cl}]$ & $p$ value & $n(\%)$ & OR $[95 \% \mathrm{Cl}]$ & $p$ value \\
\hline \multicolumn{10}{|l|}{ Age } \\
\hline 21-30 years & $204(53.7)$ & 1 (Ref.) & & $125(32.9)$ & 1 (Ref.) & & $189(49.7)$ & 1 (Ref.) & \\
\hline $31-40$ years & $376(47.9)$ & $\begin{array}{l}0.79 \\
{[0.62-1.02]}\end{array}$ & 0.07 & $242(30.9)$ & $\begin{array}{l}0.91 \\
{[0.70-1.18]}\end{array}$ & 0.48 & $468(59.7)$ & $\begin{array}{l}1.49 \\
{[1.17-1.91]}\end{array}$ & $<0.01$ \\
\hline $41-50$ years & $210(43.9)$ & $\begin{array}{l}0.68 \\
{[0.52-0.88]}\end{array}$ & $<0.01$ & $118(27.7)$ & $\begin{array}{l}0.67 \\
{[0.49-0.90]}\end{array}$ & $<0.01$ & $254(53.1)$ & $\begin{array}{l}1.15 \\
{[0.87-1.5]}\end{array}$ & 0.32 \\
\hline $51-60$ years & $85(33.3)$ & $\begin{array}{l}0.43 \\
{[0.31-0.60]}\end{array}$ & $<0.01$ & $46(18.0)$ & $\begin{array}{l}0.45 \\
{[0.31-0.66]}\end{array}$ & $<0.01$ & $108(42.3)$ & $\begin{array}{l}0.74 \\
{[0.54-1.02]}\end{array}$ & 0.07 \\
\hline$>61$ years & $28(21.7)$ & $\begin{array}{l}0.23 \\
{[0.15-0.38]}\end{array}$ & $<0.01$ & $13(10.1)$ & $\begin{array}{l}0.23 \\
{[0.12-0.42]}\end{array}$ & $<0.01$ & $50(38.7)$ & $\begin{array}{l}0.64 \\
{[0.43-0.96]}\end{array}$ & 0.03 \\
\hline \multicolumn{10}{|l|}{ Gender } \\
\hline Male & $461(41.3)$ & 1 (Ref.) & & $279(25.0)$ & 1 (Ref.) & & $594(53.2)$ & 1 (Ref.) & \\
\hline Female & $442(48.6)$ & $\begin{array}{l}1.35 \\
{[1.13-1.61]}\end{array}$ & $<0.01$ & $265(29.1)$ & $\begin{array}{l}1.24 \\
{[1.01-1.50]}\end{array}$ & 0.03 & $475(52.2)$ & $\begin{array}{l}0.96 \\
{[0.81-1.15]}\end{array}$ & 0.68 \\
\hline \multicolumn{10}{|l|}{ Job profile } \\
\hline Administration & $44(48.9)$ & 1 (Ref.) & & $25(27.8)$ & 1 (Ref.) & & $38(42.2)$ & 1 (Ref.) & \\
\hline Doctor & $732(43.9)$ & $\begin{array}{l}0.82 \\
{[0.53-1.25]}\end{array}$ & 0.35 & $423(25.4)$ & $\begin{array}{l}0.89 \\
{[0.55-1.42]}\end{array}$ & 0.38 & $893(53.6)$ & $\begin{array}{l}1.64 \\
{[1.03-2.42]}\end{array}$ & 0.04 \\
\hline Paramedic & $23(53.4)$ & $\begin{array}{l}1.20 \\
{[0.58-2.49]}\end{array}$ & 0.31 & $16(37.2)$ & $\begin{array}{l}1.54 \\
{[0.71-3.33]}\end{array}$ & 0.13 & $20(46.5)$ & $\begin{array}{l}1.19 \\
{[0.57-2.47]}\end{array}$ & 0.32 \\
\hline Nurse & $101(51.1)$ & $\begin{array}{l}1.09 \\
{[0.66-1.79]}\end{array}$ & 0.37 & 76 (38.9) & $\begin{array}{l}1.62 \\
{[0.94-2.79]}\end{array}$ & 0.04 & $96(48.5)$ & $\begin{array}{l}1.29 \\
{[0.78-2.13]}\end{array}$ & 0.16 \\
\hline Support staff & $3(10.7)$ & $\begin{array}{l}0.13 \\
{[0.35-0.44]}\end{array}$ & $<0.01$ & $4(14.3)$ & $\begin{array}{l}0.44 \\
{[0.14-1.37]}\end{array}$ & 0.08 & $22(78.6)$ & $\begin{array}{l}5.02[1.85- \\
13.57]\end{array}$ & $<0.01$ \\
\hline \multicolumn{10}{|l|}{ Work environment } \\
\hline Low risk & $117(41.3)$ & 1 (Ref.) & & $60(21.2)$ & 1 (Ref.) & & $129(45.6)$ & 1 (Ref.) & \\
\hline High risk & $786(45.1)$ & $\begin{array}{l}1.16 \\
{[0.90-1.50]}\end{array}$ & 0.24 & $484(27.8)$ & $\begin{array}{l}1.43 \\
{[1.05-1.94]}\end{array}$ & 0.02 & $940(53.9)$ & $\begin{array}{l}1.40 \\
{[1.08-1.79]}\end{array}$ & $<0.01$ \\
\hline
\end{tabular}

*Binary regression analysis was not done, as there were only four independent variables, and of these, only two were significant on univariate analysis for each type of burnout

\section{Discussion}

This is the first Indian study ( $n=2026)$ on burnout among HCWs, based on $\mathrm{CBI}$, conducted during the ongoing COVID-19 pandemic. We found that as compared to normal circumstances, there was a significant increase in pandemic-related burnout. There are multiple instruments available for assessing burnout in the literature, $\mathrm{MBI}$, $\mathrm{MBI}-$ General Survey (MBI-GS), Oldenburg Burnout Inventory (OLBI), and Shirom-Melamed Burnout Measure (SMBM). ${ }^{10} \mathrm{MBI}$ is the oldest and most commonly used inventory. ${ }^{11-13}$ Many drawbacks of MBI have been described, such as a circular argument and unclear relationship with the concept of burnout. The other problems seem to be that it presents a mixture of effects of burnout and coping strategies and has unacceptable questions. All items in $\mathrm{MBI}$ are negatively phrased, with more emphasis on emotional aspects of exhaustion, and a commercial publisher holds its copyright.

We therefore chose to base our questionnaire on the $\mathrm{CBI}$, with appropriate modification, as it has been shown to be a simple, comprehensive, reliable, self-explanatory, reliable, easy-tounderstand. It has excellent psychometric properties to measure burnout in $\mathrm{HCWs} .{ }^{714}$ It includes items, with mixture of positive and negative phrases, covering physical and cognitive aspects of exhaustion and is free to use. We found it more appropriate for the current pandemic scenario as it comprises three independent domains reflecting different aspects of HCWs activities, with more discriminatory power.

We found a high prevalence of burnout during the current pandemic compared to pre-COVID-19 era. This is difficult to compare with previous literature as most studies had used different scales. We found that the mean score of pandemic-related burnout in the HCWs was significantly higher than the mean personal and work-related scores (51.37 vs both, 49.72, 39.69, respectively, $p<$ 0.05).

Burnout in HCWs, particularly doctors, has been shown to cause increased medical errors. ${ }^{15-17}$ It can lead to decreased patient satisfaction and thus increases the chances of litigation. In personal life, there are increased chances of depression, possibly leading to substance abuse. There is deterioration in interpersonal relationship. Many physicians will retire due to burnout, adding to the loss of an already scarce resource.

Burnout in HCWs is multifactorial and has been shown to cause detrimental effect during previous pandemics. During the first pandemic of the century, SARS, a questionnaire-based survey in the staff working in the EDs, revealed a significantly 
high distress levels in the nursing staff, doctors, and healthcare assistants in decreasing trend, in that order. ${ }^{18}$ The psychological distress for HCWs working in pandemic has been attributed to various factors such as possibility of quarantine, fear of infections due to contagious nature of disease, concern for self and family, job stress, interpersonal isolation, perceived stigma, fear of doing unfamiliar work (for non-ICU/ED HCWs), etc. ${ }^{19}$ The effect of the pandemic can be long lasting as well. Maunder et al. assessed the long-term psychological effects in Canadian HCWs, after 1-2 years of the SARS pandemic. As compared to their colleagues who did not look after the SARS patients, the HCWs in Toronto and Hamilton had significantly higher burnout (MBI-EE) scores (30.4 vs 19.2, $p=$ $0.003)$, psychological distress scores (44.9 vs $30.2, p<0.001)$, and posttraumatic stress scores (13.8 vs $8.4, p=0.06){ }^{19}$

The best way to assess and diagnose burnout is still under research; therefore, literature on burnout gives a variable incidence from $18 \%$ to $82 \% .{ }^{11}$ COVID-19 outbreak with its rapid global spread, possibly worsened the burnout, as it has presented unprecedented challenges to the HCWs. Another study done on medical residents, in the pre-COVID period, also showed a wide range of burnout prevalence, i.e., $27-75 \% .{ }^{20}$ In an Indian survey done using e-mails, 445 (out of 1721, 27.7\%) responded. The survey was based on Patient Health Questionnaire-9 (PHQ-9), Cohen's Perceived Stress Scale (PSS), and MBI. ${ }^{21}$ Most respondents were residents (376). Two-thirds (67.2\%) of the respondents had experienced moderate level of stress, while $13 \%$ reported high stress levels. Some level of burnout was present among $>90 \%$ of the respondents. Overall, the mean burnout score was 42.4 ( \pm SD - 15.15). The mean score was higher in residents than in faculty $(43.5 \pm 15.2$, vs $36.8 \pm 13.6)$.

The burnout studies in the pre-COVID-19 era using CBI scale used clients as patient, patient care, job, etc. ${ }^{22}$ It is noteworthy that in the pre-COVID era, the client domain showed lower burnout scores than other domains. A study among 210 pediatricians showed only $22 \%$ overall incidence. Of this, only $8 \%(n=16)$ pediatricians had client-related burnout compared to $22 \%(n=46)$ personal and $14 \%$ $(n=30)$ work-related burnout. ${ }^{23}$ The overall burnout and burnout in three domains was mainly related to job insecurity, high workload and lack of job satisfaction. ${ }^{23}$ Žutautienè et al. also found low prevalence of client-related (job) burnout (35.1\%) compared to the personal (44.8\%) and work-related (46.7\%) burnout. ${ }^{24}$ Ratnakaran et al. used CBI to assess burnout in residents and postgraduate trainees of different disciplines in a Kerala hospital in the pre-COVID-19 era. ${ }^{25}$ More than half respondents (55.2\%) reported burnout. The incidence of personal (64.05\%), work-related (28.1\%), and clientrelated burnout (68.62) was highest in the interns. The incidence was lowest in superspecialty postgraduate trainees and for those working in nonmedicine, nonsurgical branches. Worry about the career going forward, being not involved in the decision-making process, and rotations in different departments, with changing patient profile, may have caused high personal and patient-related burnout among interns. Contrary to this, the superspecialty senior residents have a defined career path and their own identity. Another pre-COVID-19 study, among 300 residents working in public hospitals in Mumbai, found a high prevalence of personal (66.67\%) and work-related (57.14\%) burnout. In comparison, incidence of client-related burnout was low (16.67\%). ${ }^{26}$

An Ethiopian study of $334 \mathrm{HCWs}$, mainly paramedics (there were only 15 physicians), found that the overall prevalence of burnout was $39.7 \%$. The incidence of burnout was highest among nurses $(82.8 \%)$, while it was lowest in laboratory technicians
$(2.8 \%){ }^{27}$ The predictors of burnout were lack of interest in the job, insecurity, history of physical illness, poor relationship with superiors, worry about getting infected or falling ill. A recent systematic review of five studies on burnout reported that the prevalence of burnout ranged from 16 to $50 \% .{ }^{28}$ The three studies which used $\mathrm{CBI}$ reported higher rates of personal and workrelated burnouts. The rate of client-related burnout was lowest in all three studies. The studies, using $\mathrm{CBI}$, had higher burnout prevalence as compared to those, which used MBI and General Burnout Measure. These findings suggest that in pre-COVID era, paramedics had minimum client-related burnout. The burnout in paramedics was probably due to long working hours, job insecurity, being undervalued as work force, poor remuneration, and lack of support from superiors.

The dynamics have drastically been changed in the COVID-19 era. We found prevalence of client-related burnout (pandemicrelated) to be highest in all categories of HCWs. An early study from Hubei province in China compared the mental health disturbances in physicians and nurses working at frontline and the second-line workers. ${ }^{8}$ Those who were directly involved in diagnosis and treatment of COVID-19 patients showed a higher incidence and more severe symptoms of depression, anxiety, insomnia, and mental distress. The chances of having severe symptoms increased if the respondents were females, intermediate seniority, and working at the frontline.

Many respondents in our study had fear of contracting COVID19 infection during work $(1,120,55.3 \%)$ and carrying infection home to family members $(1,357,66.9 \%)$. This was similar to the findings of the SCCM COVID-19 Rapid-Cycle Survey 2, carried out in April 7-22, 2020. Of 9,492 ICU HCWs, nearly 6,500 had some measures in mind to prevent family members getting infected due to them. On a scale of 0 to 10 , the level of concern about personally being exposed to COVID-19 was 8 (median, IQR 6-10) and the level of concern about exposing family members to COVID-19 was 10 (median, IQR 7-10). ${ }^{29}$ One multicenter cross-sectional survey also has shown that the history of contact with the patient was an independent risk factor, and it doubled the risk of anxiety and depression during the COVID19 pandemic $(n=958){ }^{30}$

A meta-analysis of 13 studies, which included 33,062 HCWs, found that females had higher anxiety and depression as compared to males. ${ }^{31}$ Nurses had higher incidence of anxiety and depression. This is similar to our finding of female respondents having higher ORs for personal [1.35 (1.13-1.61), <0.01] and work-related [1.24 (1.01-1.50), $p<0.03$ ] but similar [0.96 (0.81-1.15), $p=0.68$ ] pandemic-related burnout. Albert suggested that the risk factors for depression in women are likely to be of biological origin, such as fluctuations in the hormone level, as seen during the changes in menstrual cycle. ${ }^{32}$ This difference may also be affected by the innate differences in strength and personality as compared to males. One study from Singapore during the COVID-19 pandemic observed higher prevalence of anxiety, depression, and stress but not PTSD among medical than nonmedical HCWs. ${ }^{33}$ In contrast, another study reported higher prevalence of psychological problems in medical health workers as compared to nonmedical health workers during COVID-19 pandemic. ${ }^{34}$ We found low incidence of substance abuse $(108,5.3 \%)$ in our survey. Grover et al. reported very low prevalence of substance abuse among the faculty and residents, in a study from North India. This was in spite of high and moderate level stress and nearly $17 \%$ suicidal ideations among the respondents. ${ }^{21}$ Another study conducted among internal medicine residents had shown 
only $9 \%$ were at risk of alcohol abuse in spite of high burnout of $76 \%$. $^{35}$

We feel that a multipronged approach is necessary to prevent and ameliorate the effects of burnout among HCWs. This will not only protect the HCWs but in the long run may be beneficial for the society, by preventing the collapse of the health services. Dissatisfaction with the job, high workload, feeling of not being appreciated by senior management, inadequate remuneration, failure to achieve goals, poor interpersonal relationships at workplace, competing family interests with lack of time with family can all contribute to the development of burnout. During this pandemic, in particular, lack of adequate PPE, staff shortage due to inability of other HCWs to travel to the hospital on top of the fear of contracting infection and spreading it to family members have added to the stress and anxiety among the HCWs. Institutional leadership should create protective and supportive working environment. They should provide information, instructions, training, and technical updates on COVID-19 through frequent communication. HCWs should be given a sense of safety by supplying adequate PPEs, avoiding prolonged working hours, assuring compensation, rehabilitation, curative services, and counseling services. They should create a working environment which will boost the confidence and moral of HCWs and help the recovery of those who are already suffering. ${ }^{36}$ At personal level, every HCW should focus on self-care and destressing by adopting personalized resilience plan and workshop-based training. One can refer to the computer-assisted resilience training, and digital learning packages (e-package) can be used for psychological wellbeing. ${ }^{36,37}$ In case of suffering, expressing and taking help from the colleagues or an expert should be the priority.

This survey has some limitations. First, being an anonymous survey, a possibility of lack of uniformity, variability of responses, and regional bias cannot be ruled out. Another limitation of our study was that most participants in our survey were working in the high-risk areas. This is most probably due to the fact that all the investigators themselves work in high-risk areas, and therefore their contacts, which were sent the questionnaire, are likely to be working in similar areas of their hospitals. We also did not ask the respondents whether any of them had past psychiatric issues, but the presence of such issues may influence the results of such studies. The HCWs were all working in different environments, which might have differences and the effect of this cannot be appreciated. We also did not include the questions about the marital status, availability of PPE, and the extent of workload. Lastly, selfreporting bias, depending upon the interest level and mindset of the respondent, cannot be ruled out. Follow-up studies are required to assess and analyze the long-term impact of this pandemic if the situation worsens further.

\section{Conclusion}

In this first Indian survey of HCWs during the COVID-19 pandemic, we found a high level of pandemic-related burnout among HCWs. The female respondents had higher chances of getting personal and work-related burnout, and this may be related to the dual role the females play in running the house, apart from working in the healthcare sector. The common concerns seemed to be fear of catching infection and, thereby, infecting the family members. The respondents also were worried about dying due to COVID-19 infection. We feel that ensuring the well-being of HCWs is essential to preserving this most important asset, during the bad time for healthcare sector, in particular, and society, in general. Interventions at organizational level such as promoting preemptive resilience strategies and by providing worker friendly environment will go a long way in decreasing stress and burnout in HCWs.

As physicians we owe our patients two things - only two thingsour time and our skill. We do not owe our patients our lives.

-Joseph D Wassersug, MD

\section{References}

1. Freudenberger HJ. Staff burnout. J Soc Issues 1974;30(1):159-165. DOI: 10.1111/j.1540-4560.1974.tb00706.x.

2. Maslach C. Burned-out. Hum Behav 1976;9:16-22.

3. Maslach C, Jackson SE. The measurement of experienced burnout. J Occup Behav 1981;2(2):99-113. DOI: 10.1002/job.4030020205.

4. Kisely S, Warren N, McMahon L, Dalais C, Henry I, Siskind D. Occurrence, prevention, and management of the psychological effects of emerging virus outbreaks on healthcare workers: rapid review and meta-analysis. BMJ 2020;369:m1642. DOI: 10.1136/bmj. m1642.

5. Shanafelt TD, Gorringe G, Menaker R, Storz KA, Reeves D, Buskirk SJ, et al. Impact of organizational leadership on physician burnout and satisfaction. Mayo Clin Proc 2015;90(4):432-440. DOI: 10.7326/00034819-136-5-200203050-00008.

6. World Health Organization, Mental health and psychosocial considerations during the COVID-19 outbreak, 2020. World Health Organization. https://apps.who.int/iris/handle/10665/331490.

7. Kristensen TS, Borritz M, Villadsen E, Christensen KB. The Copenhagen burnout inventory: a new tool for the assessment of burnout. Work Stress 2005;19(3):192-207. DOI: 10.1080/02678370500297720.

8. Lai J, Ma S, Wang Y, Cai Z, Hu J, Wei N, et al. Factors associated with mental health outcomes among health care workers exposed to coronavirus disease 2019. JAMA Netw Open 2020;3(3):e203976. DOI: 10.1001/jamanetworkopen.2020.3976.

9. Xiao H, Zhang Y, Kong D, Li S, Yang N. The effects of social support on sleep quality of medical staff treating patients with coronavirus disease 2019 (COVID-19) in january and february 2020 in China. Med Sci Monit 2020;26:e923549. Available from: 10.12659/MSM. 923549.

10. Bianchi R. What is "severe burnout" and can its prevalence be assessed? Intensive Care Med 2015;41(1):166. DOI: 10.1007/s00134014-3534-y.

11. Prins JT, Gazendam-Donofrio SM, Tubben BJ, van der Heijden FM, van de Wiel HB, Hoekstra-Weebers JE. Burnout in medical residents: a review. Med Educ 2007;41(8):788-800. DOI: 10.1111/j.13652923.2007.02797.x.

12. Kesarwani V, Husaain ZG, George J. Prevalence and factors associated with burnout among healthcare professionals in India: a systematic review and meta-analysis. Indian J Psychol Med 2020;42(2):108-115. DOI: 10.4103/IJPSYM.IJPSYM_387.

13. Dubale BW, Friedman LE, Chemali Z, Denninger JW, Mehta DH, Alem $A$, et al. Systematic review of burnout among healthcare providers in sub-Saharan Africa. BMC Public Health 2019;19(1):1247. DOI: 10.1186/ s12889-019-7566-7.

14. Peter W, Anthony W. Comparing two measures of burnout among dentists in Australia. Int J Stress Manag 2004;11(3):282. DOI: 10.1037/1072-5245.11.3.282.

15. Shanafelt TD, Balch CM, Bechamps G, Russell T, Dyrbye L, Satele D, et al. Burnout and medical errors among American surgeons. Ann Surg 2010;251(6):995-1000. DOI: 10.1097/SLA.0b013e3181bfdab3.

16. Fahrenkopf AM, Sectish TC, Barger LK, Sharek PJ, Lewin D, Chiang VW, et al. Rates of medication errors among depressed and burnt out residents: prospective cohort study. BMJ 2008;336(7642):488-491. DOI: 10.1136/bmj.39469.763218.BE.

17. Gergen Barnett KA. In pursuit of the fourth aim in health care: The joy of practice. Med Clin North Am 2017;101(5):1031-1040. DOI: 10.1016/j. mcna.2017.04.014. 
18. Wong TW, Yau JKY, Chan CLW, Kwong RSY, Ho SMY, Lau CC, et al. The psychological impact of severe acute respiratory syndrome outbreak on healthcare workers in emergency departments and how they cope. Eur J Emerg Med 2005;12(1):13-18. DOI: 10.1097/00063110-2005.

19. Maunder R, Lancee W, Balderson K, Bennett J, Borgundvaag B, Evans S, et al. Long-term psychological and occupational effects of providing hospital healthcare during SARS outbreak. Emerg Infect Dis 2006;12(12):1924-1932. DOI: 10.3201/eid1212.060584.

20. Martini S, Arfken CL, Churchill A, Balon R. Burnout comparison among residents in different medical specialties. Acad Psychiatry 2004;28(3):240-242. DOI: 10.1176/appi.ap.28.3.240.

21. Grover S, Sahoo S, Bhalla A, Avasthi A. Psychological problems and burnout among medical professionals of a tertiary care hospital of North India: a cross-sectional study. Indian J Psychiatry 2018;60(2):175-188. DOI: 10.4103/psychiatry.IndianJPsychiatry_2.

22. Klein J, Grosse Frie K, Blum K, von dem Knesebeck O. Burnout and perceived quality of care among German clinicians in surgery. Int J Qual Health Care 2010;22(6):525-530. DOI: 10.1093/intqhc/mzq056.

23. Wright JG, Khetani N, Stephens D. Burnout among faculty physicians in an academic health science centre. Paediatr Child Health 2011;16(7):409-413. DOI: 10.1093/pch/16.7.409.

24. Žutautienè R, Radišauskas R, Kaliniene G, Ustinaviciene R. The prevalence of burnout and its associations with psychosocial work environment among Kaunas region (Lithuania) hospitals' physicians. Int J Env Res Public Heal 2020;17(10):3739. DOI: 103390/ ijerph17103739.

25. Ratnakaran B, Prabhakaran A, Karunakaran V. Prevalence of burnout and its correlates among residents in a tertiary medical center in Kerala, India: a cross-sectional study. J Postgrad Med 2016;62(3):157161. DOI: 10.4103/0022-3859.184274.

26. Dhusia AH, Dhaimade PA, Jain AA, Shemna SS, Dubey PN. Prevalence of occupational burnout among resident doctors working in public sector hospitals in Mumbai. Indian J Community Med 2019;44(4):352356. DOI: 10.4103/ijcm.IJCM_78_19.

27. Biksegn A, Kenfe T, Matiwos S, Eshetu G. Burnout status at work among health care professionals in a tertiary hospital. Ethiop J Health Sci 2016;26(2):101-108. DOI: 10.4314/ejhs.v26i2.3.
28. Reardon $M$, Abrahams R, Thyer L, Simpson P. Review article: prevalence of burnout in paramedics: a systematic review of prevalence studies. Emerg Med Australas 2020;32(2):182-189. DOI: 10.1111/1742-6723.13478.

29. Society of critical care medicine COVID-19 rapid cycle survey work group: SCCM COVID-19 rapid-cycle survey 2 report globally. Soc Crit Care Med 2020. 1-8.

30. Xiao X, Zhu X, Fu S, Hu Y, Li X, Xiao J. Psychological impact of healthcare workers in China during COVID-19 pneumonia epidemic: a multi-center cross-sectional survey investigation. J Affect Disord 2020;274:405-410. DOI: 10.1016/j.jad.2020.05.081.

31. Pappa S, Ntella V, Giannakas T, Giannakoulis VG, Papoutsi E, Katsaounou P. Prevalence of depression, anxiety, and insomnia among healthcare workers during the COVID-19 pandemic: a systematic review and meta-analysis. Brain Behav Immun 2020;88:901-907. DOI:10.1016/j.bbi.2020.05.026.

32. Albert PR. Why is depression more prevalent in women? J Psychiatry Neurosci 2015;40(4):219-221. DOI: 10.1503/jpn.150205.

33. Tan BYQ, Chew NWS, Lee GKH, Jing M, Goh Y, Yeo LLL, et al. Psychological impact of the COVID-19 pandemic on health care workers in Singapore. Ann Intern Med 2020(4):M20-1083. DOI: 10.7326/M20-1083.

34. Zhang WR, Wang K, Yin L, Zhao WF, Xue Q, Peng M, et al. Mental health and psychosocial problems of medical health workers during the COVID-19 epidemic in China. Psychother Psychosom 2020(4):1-9. DOI: 10.1159/000507639.

35. Shanafelt TD, Bradley KA, Wipf JE, Back AL. Burnout and self-reported patient care in an internal medicine residency program. Ann Intern Med 2002;136(5):358-367. DOI: 10.7326/0003-4819-136-5-20020305000008.

36. Blake $H$, Bermingham $F$, Johnson $G$, Tabner A. Mitigating the psychological impact of COVID-19 on healthcare workers: a digital learning package. Int J Environ Res Public Health 2020;17(9):2997. DOI: 10.3390/ijerph17092997.

37. Aziz S, Arabi YM, Alhazzani W, Evans L, Citerio G, et al. Managing ICU surge during the COVID-19 crisis: Rapid guidelines. Intensive Care Med 2020(7):1-23. DOI: 10.1007/s00134-020-06092-5. 


\section{Supplementary Material For "Burnout among Healthcare Workers during COVID-19 Pandemic in India: Results of a Questionnaire-based Survey"}

\section{The Introductory Note and the Questions Used in the Survey}

Work related stress has always been a cause for burn out among health care professionals. COVID-19 pandemic is an added burden. We are conducting a survey to assess impact of COVID-19 on burn out among health care workers. This survey is based on Copenhagen burn out inventory (CBI) scale. Kindly spare 5 minutes and open the link below to fill out a form. It is an anonymous survey with complete assurance of privacy. Your identity, profession and responses will never be revealed to anyone. We appeal you to participate. Please fill the following Google to send your responses.

*If you are attempting this survey on mobile phone please use landscape mode (by rotating mobile screen) to visualise all five options* Prevalence of burnout among health care workers across India during COVID-19 pandemic: A questionnaire-based survey

Please note that this is an anonymous survey and your name and profession will not be revealed.

\section{General Questions}

1. What is your job profile in health care sector (Please choose category)?

- Doctor

- Paramedic (nurse, dietician, physiotherapist, pharmacist etc)

- Ward boy

- Administration staff

2. What is your age?

- 21-30 year's

- 31-40 year's

- 41-50 year's

- 51-60 year's

- >61 year's

3. Gender

- Male

- Female

4. Do you feel mental health is equally important as physical health?

- Yes

- No

5. How is your working environment?

- High risk (ER, OPD, Wards, ICU, OT)

- Low risk (other areas)

\section{Personal Burnout}

Following questions are to assess personal burn out regardless of COVID-19 scenario:

1. How often are you physically exhausted?

2. How often are you emotionally exhausted?

3. How often do you think: "I can't take it anymore?"

4. How often do you feel weak and susceptible to illness?

5. How often do you feel worn out (extremely tired)?

\section{Work-related Burnout}

Following questions are to assess work burn out regardless of COVID-19 scenario:

1. Are you exhausted in the morning at the thought of another day at work?

2. Do you feel that every working hour is tiring for you?

3. Do you have enough energy for family and friends during leisure time?

4. Do you feel that your work is emotionally exhausting?

5. Does your work frustrate you?

6. Do you feel burnt out (complete physical or mental exhaustion) because of your work? 


\section{Client Related}

Following questions are to assess burn out because of current scenario - COVID-19:

1. Do you feel it is hard to work in the current scenario?

2. Does it drain more of your energy to work during the current scenario?

3. Do you find it fruitful while performing your work during the current scenario?

4. Do you feel that you are giving more than what you get back while working in the current scenario?

5. Do you hesitate to work during this current scenario?

6. Do you feel depressed because of the current scenario?

7. Do you feel that your patience is tested while working in the current scenario?

8. Do you feel lock down due to the current scenario has added stress on you?

9. Do you have fear to catch COVID-19 infection while working in the current scenario?

10. Do you have a fear of family members catching infection because of your work exposure?

11. Do you feel welcomed by the community because you are a health care worker and working in the current scenario?

12. Are you indulging in any substance abuse (alcohol/drugs/smoking) during this period of lockdown?

13. Do you have a fear of death while working in the current scenario?

14. Do you feel you are being properly protected by the hospital while working in the current scenario?

15. Do you feel you are being supported by colleagues during the current scenario? 